Journal of

Dentistry and Oral Health

\title{
Mandibular Two-Implant Retained Overdenture in A Patient with Parkinson's Disease: A case report
}

\section{Peter Kuyaya Welime*}

Department of Conservative Dentistry and Prosthetics, Moi University, School of Dentistry, Kenya

${ }^{*}$ Corresponding author: Peter Kuyaya Welime, P.O Box 4606 - 30100 Eldoret, Kenya; Email: welime@mu.ac.ke; Tel: +254705302385

Received Date: June 13, 2019 Accepted Date: July 08, 2019 Published Date: July 09, 2019

Citation: Peter Kuyaya Welime (2019) Mandibular Two-Implant Retained Overdenture in A Patient with Parkinson's Disease: A case report. J Dent Oral Health 6: 1-5.

\begin{abstract}
This is a case report of a 69-year-old patient with Parkinson's disease in need of maintenance of a two-implant mandibular overdenture. The report highlights advantages and challenges of choosing this modality of treatment over the convention mandibular denture. The two-implant mandibular overdenture significantly improved denture stability and retention for this patient. These findings are in line with the McGill consensus statement, the York consensus statement, and Meta-Analysis of Randomized Controlled Trials comparing two-implant overdentures and conventional mandibular complete dentures. Although the two-implant retained overdenture has numerous advantages over the conventional removable mandibular denture, it requires routine maintenance to be successful. Both the initial cost and the maintenance cost of these prostheses must be addressed for them to gain widespread acceptance.
\end{abstract}

Keywords: Edentulousness; Implants; Overdenture; Parkinson's disease

Key Messages: The present case report describes how a two-implant mandibular overdenture significantly improved denture stability and retention for a 69-year-old patient with Parkinson's disease.

(C)2019 The Authors. Published by the JScholar under the terms of the Creative Commons Attribution License http://creativecommons.org/licenses/ by/3.0/, which permits unrestricted use, provided the original author and source are credited. 


\section{Introduction}

The conventional removable complete mandibular denture, especially in severely resorbed ridges has many documented shortcomings [1]. Because of these problems, there has been intense debate in published literature on how best to treat the edentulous mandible $[2,3,4,5,6,7]$. The McGill consensus statement expressly states that the conventional mandibular complete denture is no longer the most appropriate first choice treatment for the edentulous mandible [2]. However, patient related factors influence treatment planning for edentate patients [6]. This case report seeks to highlight the benefits and challenges of the two-implant mandibular overdenture in a patient with Parkinson's disease.

\section{Case history}

A 69-year-old female patient visited a University Dental Hospital seeking maintenance care of her mandibular twoimplant overdenture. In the past 1 year, she had had trouble with speech and mastication because of the mandibular denture looseness. She had been a denture wearer for the past 12 years. The upper denture was still comfortable and serving her well. The first lower denture was loose since insertion and was subsequently replaced 6 years later with an implant retained overdenture. She continued using the initial maxillary denture because it was more comfortable compared to the new one made with the mandibular overdenture. She had been diagnosed with Parkinson's disease 13 years ago. Parkinson's disease is a neurodegenerative disorder, which leads to progressive deterioration of motor function due to loss of dopamine-producing brain cells. The main symptoms associated with her condition were mild tremors at rest, muscle rigidity, and slowness. She had no history of stroke. She was on 4-hourly Levodopa to control her symptoms. At the most recent medical review she had been placed at disease stage 2 mainly due to her difficulty with speech and mastication. The loose overdenture was therefore worsening the effect of Parkinson's disease on her oral functions. On examination, it was found that the lower overdenture was no longer retentive especially on the right side (figure 1). The right ball abutment showed more wear than the left ball abutment (\#04M-40A, Southern Implants, Irene, South Africa) (figure 2). Since she was using a mismatched set of dentures, she had an open bite on the right side (figure 3). Radiographic examination showed that the left ball abutment screw was open allowing a $1 \mathrm{~mm}$ gap between the implant body $(10 \times 3.5 \mathrm{~mm}$, Southern implants, Irene, South Africa) and the abutment (figure 4).
The upper denture had acceptable retention but was 12 years old. To achieve retention, a balanced occlusion, and compensate for tooth wear, the following treatment was offered; 1 ) the right ball abutment was replaced with a new one (\#04M-40A, Southern Implants, Irene, South Africa), 2) the left abutment screw was tightened to $30 \mathrm{Ncm}$ ( \#06-TW30, $30 \mathrm{Ncm}$ torque wrench, Southern Implants, Irene, South Africa), 3) a new removable conventional full upper denture was fabricated, and 4) a new mandibular implant-retained and tissue-supported overdenture was fabricated with new retentive caps (UMA-O-ring system \#07-4400, Southern Implants, Irene, South Africa) (Figure 5).

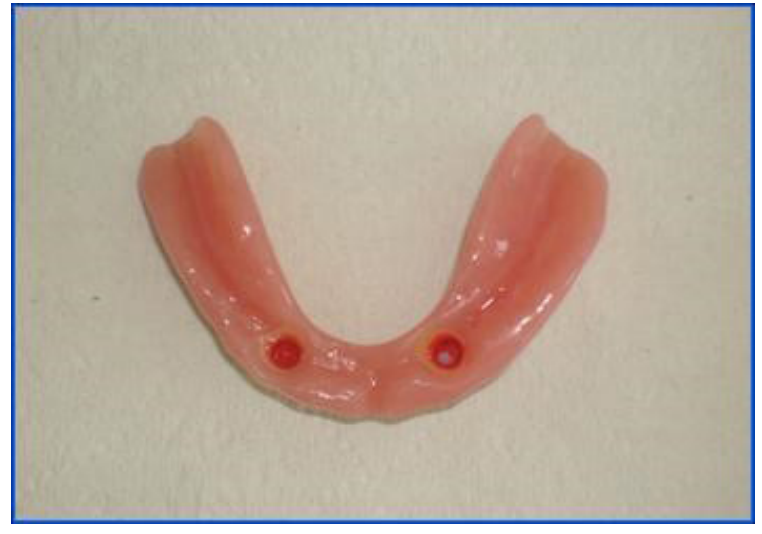

Figure 1: Non-retentive mandibular overdenture

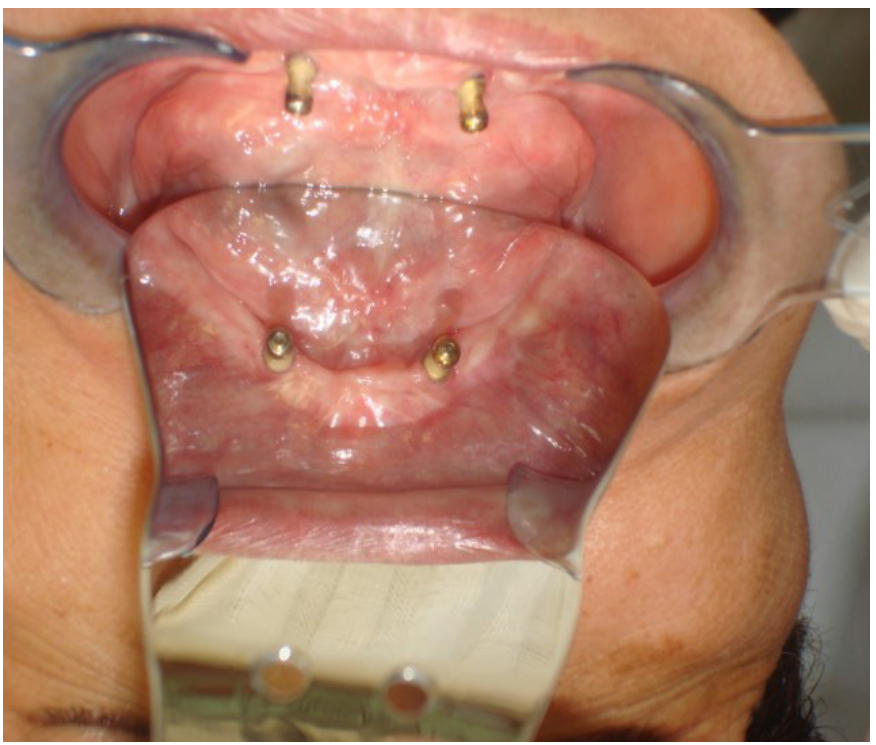

Figure 2: Right and left ball abutments 


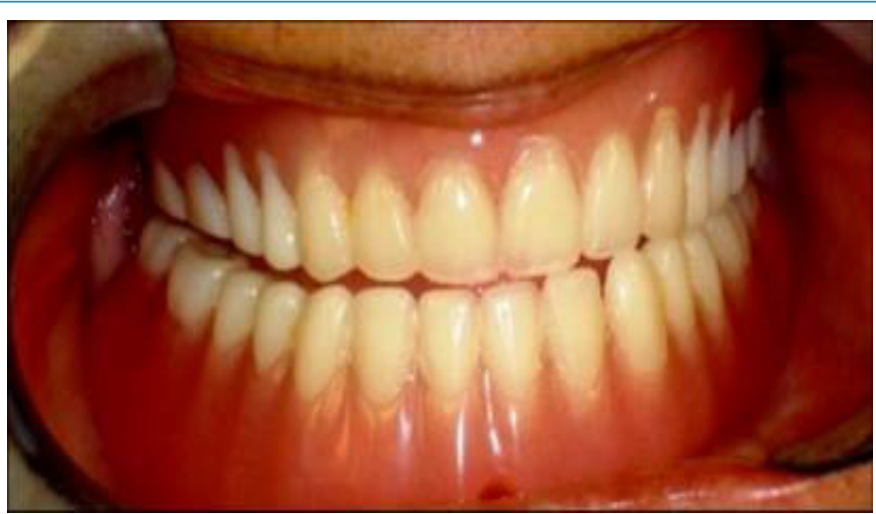

Figure 3: Mismatched dentures

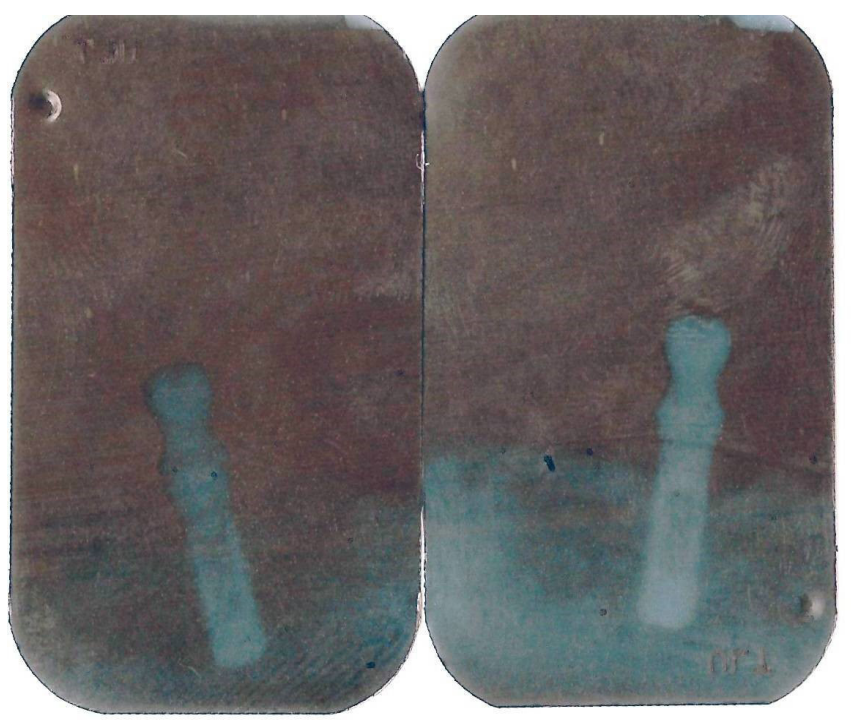

Figure 4: Open left abutment screw

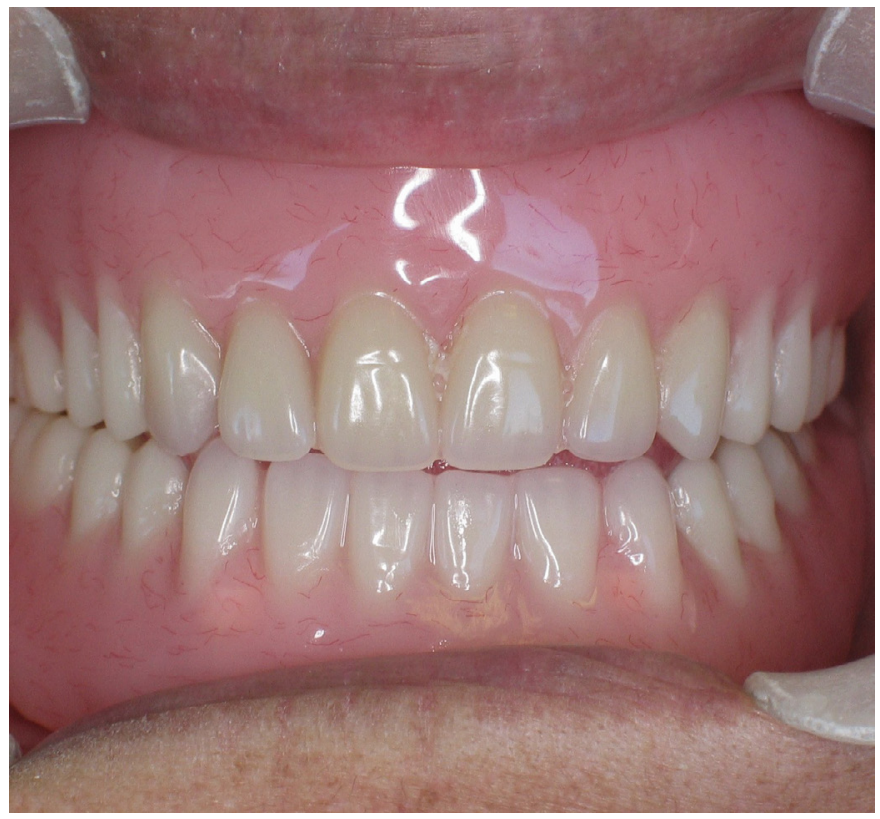

Figure 5: New dentures
Denture insertion was done with minimal occlusal adjustments. Patient review was done at 3 days, 1 week, 1 month, 3 months, and 6 months. The patient was happy with her new dentures. She reported improvement in speech and masticatory ability.

\section{Discussion}

In the most basic form of a mandibular implant-retained and tissue-supported overdenture (Overdenture option 1 or OD-1), implants are inserted in position $\mathrm{B}$ and $\mathrm{D}$ (Where $\mathrm{A}, \mathrm{B}, \mathrm{C}, \mathrm{D}$, and $\mathrm{E}$ are equal columns of the mandible between the mental foramina beginning from the patient's right side) [8]. The implants remain independent of each other and are not connected by a superstructure. The function of implants in this type of prosthesis is primarily retention but not support [9]. The overdenture is made to full extension as with the conventional denture to maximize on areas of support. The most common type of attachment used in an OD-1 is an O-ring design and the prosthesis movement should be as much as is practical [8]. This type of prosthesis is ideal for patients who complain of looseness and mobility, but not of soreness of the mucosa when using a conventional mandibular denture [9]. In addition, the bone quality must be good, implants must be at least $8 \mathrm{~mm}$ long and $3.5 \mathrm{~mm}$ wide, and the divergence of implants should be less than 20 degrees [8].

The mandibular implant overdenture provides several advantages over a conventional complete mandibular denture [9]. The placement of implants enhances the support, retention and stability of an overdenture [9]. Due to the continued alveolar bone resorption under conventional dentures, it has been suggested that every completely edentulous patient should have at least an implant overdenture in the mandible to reduce such bone resorption [8]. It has been reported that about $4 \mathrm{~mm}$ of vertical bone loss occurs in the first year following extractions and the resorption continues over the next 25 years with the mandible showing 4 times more resorption than the maxilla. ${ }^{[10]}$ However, mandibular implant overdentures minimize anterior residual ridge resorption. About $0.6 \mathrm{~mm}$ bone loss has been reported under implant overdentures over 5 years and the longterm resorption is thought to remain below $0.1 \mathrm{~mm}$ per year $[8,11]$. Continued bone loss in the edentulous mandible may compromise not only function with the conventional denture but also aesthetics [1]. With the implant overdenture, teeth can be placed in more aesthetic locations compared to the conven- 
tional mandibular denture without compromising stability [12]. This is possible because of the improved resistance of the implant overdenture.

Due to the improved stability, the mandibular overdenture prosthesis remains in place during speech and mastication. Therefore, the tongue and perioral musculature may resume a more normal position because they are not required to limit the mandibular prosthesis movement. There is improved chewing efficiency and biting force with implant overdentures [1]. It has been reported that the maximum occlusal force of a patient with dentures may improve 300\% with an implant-supported prosthesis [8]. Implant supported prosthesis do not require extensive soft tissue coverage [8]. The flexibility in the amount of coverage is possible because the prosthesis stability is provided by the implants. New denture wearers, patients with tori, or those with low gagging thresholds can greatly benefit from the reduced prosthesis coverage. Exaggerated facial contours can be avoided in patients with recent extractions by using reduced coverage. In addition, patients with soft and hard tissue defects may be restored successfully with implant overdentures because the prosthesis is mainly stabilized by the implants.

For this Parkinson's disease patient, denture maintenance was a key component of the overall management to improve her quality of life. It has been reported that if well managed, patients with Parkinson's disease can lead long, productive lives with life expectancy about the same as people without the disease [13]. The implant-retained mandibular overdenture greatly improved denture stability for this patient. Subsequent reviews at 3 days, 1 week, 1 month, 3 months, and 6 months showed significant improvement in speech and reported masticatory ability.

The primary symptoms of Parkinson's disease are all related to voluntary and involuntary motor function and usually start on one side of the body. Symptoms are mild at first but progress over time. Studies have shown that by the time that primary symptoms appear, individuals with Parkinson's disease will have lost $60 \%$ to $80 \%$ or more of the dopamine-producing cells in the brain [13]. Progressive loss of motor function and continued brain damage can lead to secondary symptoms such as anxiety, confusion, memory loss, and swallowing difficulty. The importance of team approach in the management of these patients therefore cannot be overstated.
Although implant overdentures are excellent prostheses, they present with a few disadvantages. Overdentures are still removable despite having excellent stability. Implant overdentures require more prosthetic space than fixed implant prosthesis [12]. To accommodate all the components and the soft tissues, at least a height of $15 \mathrm{~mm}$ is required between the occlusal plane and Implant platform [8]. Maintenance costs of an implant overdenture are much higher than for a conventional denture and significantly higher than that for an implant supported fixed prosthesis [12]. Attachments such as O-rings and clips wear and must be replaced. A new overdenture is often required every seven years due to denture-tooth wear and soft tissue support changes [8].

\section{Conclusion}

The two-implant mandibular overdenture significantly improved denture stability and retention for this 69-year-old Parkinsonism patient. It would have been difficult to achieve similar retention and stability with a conventional mandibular denture [1]. The outcome of this case is in line with the findings of Kodama et al. in a Meta-Analysis involving two-implant overdentures and conventional dentures [4]. Although the implant retained overdenture has numerous advantages over the conventional removable mandibular denture, it requires routine maintenance to be successful [14]. Both the initial cost and the maintenance cost of these prostheses must be addressed for them to gain wide acceptance. 


\section{References}

1. Doundoulakis JH, Eckert SE, Lindquist CC, Jeffcoat MK (2003) The implant-supported overdenture as an alternative to complete mandibular denture. J Am Dent Assoc 134: 1455-1458.

2. (2002) The McGill consensus statement on overdentures. Statement from Symposium held at McGill University in Montreal, Quebec, Canada on May 24-25, 2002. Int J Prosthodont 15:413-414.

3. Thomason JM, Feine J, Exley C, Moynihan P, Müller F et al. (2009) Mandibular two implant-supported overdentures as the first choice standard of care for edentulous patients -the York Consensus Statement. British Dental Journal 207:185186.

4. Kodama N, Singh BP, Cerutti-Kopplin D, Feine J, Emami E (2016) Efficacy of Mandibular 2-implant Overdenture: An Updated Meta-analysis on Patient-based Outcomes. J Dent Res 1:20-30.

5. Thomason JM, Kelly SAM, Bendkowski A, Ellis JS (2012) The implant-supported overdenture as an alternative to the mandibular conventional denture. J Dent 4:22-34.

6. Fitzpatrick B (2006) Standard of care for the edentulous mandible: a systematic review. J Prosthet Dent 95: 71-78.

7. Hamdan NM, Gray-Donald K, Awad MA, JohnsonDown L, Wollin S, et al. (2013) Do Implant Overdentures Improve Dietary Intake? A Randomized Clinical Trial. J Dent Res 92: 146S-153S.

8. Misch CE (2005) Dental implant prosthetics. Missouri: Mosby.

9. Chee W, Jivraj S (2006) The treatment planning of the edentulous mandible. BDJ 201: 337-347.

10. Tallgren A (2003) The continuing reduction of the residual alveolar ridges in complete denture wearers: A mixedlongitudinal study covering 25 years. J Prosthet Dent. 89: 427435.

11. Von Wowern N, Gotfredsen K (2001) Implant-supported overdentures, a prevention of bone loss in edentulous mandible? A 5-year follow-up study. Clin. Oral Impl Res 12: 19-25.
12. Hobkirk JA, Watson RM, Searson LJJ (2003) Introducing dental implants. London: Churchill Livingstone.

13. Sietske NH, Charles PD, Melissa CS (2019) Parkinson's Disease Symptoms, Causes, Stages, Treatment,and Life Expectancy. https://www.emedicinehealth.com/parkinsons_disease_ pd/article_em.htm

14. Chafee NR, Felton DA, Cooper LF, Palmqvist U, Smith R (2002) Prosthetic complications in an implant-retained mandibular overdenture population: initial analysis of a prospective study. J Prosthet Den 87: 40-44.

Submit your manuscript to a JScholar journal and benefit from:

- Convenient online submission

I Rigorous peer review

I Immediate publication on acceptance

ๆ Open access: articles freely available online

ब High visibility within the field

ब Better discount for your subsequent articles

Submit your manuscript at http://www.jscholaronline.org/submit-manuscript.php 